Daniel James (Yale) discerned a certain state-centered focus to the analysis, and asked how the women's question related to the broader issue of political participation and power in contemporary Cuba. James and Jiménez both called for greater attention to the distinctions among the working women being discussedsuch as the differences between urban and rural or middle- and working-class women. Peter Winn (Tufts) amplified on these comments and suggested the need for more of an internal analysis from below. Winn also pointed out that the comments of Cuban women's leader Vilma Espin were remarkably critical and would have been unheard of ten years ago. Is it Fidel Castro's support that makes this possible, he asked, to which Smith responded by citing the oft-cited comment that Fidel may in fact be Cuba's top feminist.

The explosion of interest in Latin American labor history was amply proven by the growing interest in the conference and the boom in publications in this field. Moreover, the Latin American Studies Association has made labor a theme for its September 1989 meeting in San Juan, Puerto Rico. Plans are also advancing for a Latin American Labor Studies newsletter to be published jointly at Florida International University by the Latin American and Caribbean Center and the Center for Labor Research and Studies.

\title{
Labor, the Church, and Social Justice: The Fourteenth Annual Southwest Labor Conference
}

\author{
Bill Doyle \\ Coordinator, SWLSA '88
}

At the Fourteenth Annual Southwest Labor Conference, held at Loyola Marymount University, 29-30 April 1988, priests, nun, ministers, and lay religious activists met union and community organizers on their own grounds in half a dozen workshops, exchanging views and suggesting strategies to empower the working poor.

Loyola Marymount political science professor Bill Fitzgerald placed these struggles in perspective with an analysis of the pastoral letter on the economy by the U.S. Catholic Bishops. The Director of Work, Economics, and Religion (WER) reviewed WER's campaign to organize Chicana workers at a local toy factory; writer Pat Hoffman (Ministry of the Dispossessed, 1987) summed up some of the lessons learned by clergy who had joined the Farmworkers' grape boycott; and Catholic priests Gary Smith and John Seymour reported on their successful struggle in East Los Angeles to raise the minimum wage by action from both the state legislature and the archdiocese of Los Angeles.

Church activism also surfaced in the key plenary report by Eric Mann and 
Rudy Acuña. Mann, author of Taking on General Motors (1988), described the dramatic campaign to keep GM Van Nuys open; Acuña, Professor of Mexican American Studies (California State University, Northridge), stressed the role of minority workers and the black and brown Los Angeles communities in building a strong city-wide coalition, powerful enough to make the threat to boycott GM products in the huge Los Angeles auto market an effective bargaining ploy. Acuña stressed the role of Luis Olivares and other clergy in building community support.

With twenty workshops, three plenaries, and over eighty panelists and speakers, SWLSA ' 88 was one of the more successful of recent conferences. AFLClO state leader John Henning and Los Angeles Times labor editor Harry Bernstein both addressed plenary meetings.

A sampling of papers includes one on socialism in the 1910-11 San Diego elections by Leonard Pitt (CSU, Northridge); excerpts from a prize-winning book on minority labor struggles in the Pacific by Ed Beechert (Hawaii); a look at Harry Bridges's struggles with the law in San Francisco by Bob Cherny (CSU, San Francisco); and a report on the lives of working people of Philadelphia from 1750 to 1800 by Billie G. Smith (Montana).

This mixture of scholarly and activist reports is the hallmark of the SWLSA, which, from its beginning, has welcomed members, and drawn its leadership from both academia and the workplace. The 1988 meeting at Loyola Marymount drew close to four-hundred participants; fittingly, on the second day of the conference, two-hundred students from a community college program for working adults swelled the attendance. Professor Sally Miller (University of the Pacific) is SWLSA President. Frank Stricker (CSU, Dominguez Hills) chaired a very active conference committee.

\title{
Women, Work, and Family Life
}

\author{
Miriam Frank \\ New York University
}

The labor movement in the United States, during a decade when its membership has diminished drastically (currently 17 percent of U.S. workers are organized, down from 21 percent in 1978), has significantly shaped the debate on working women's issues. Indeed, one of the few bright spots in the entire trade union picture is the story of women's increasing membership ( 33 percent of union members in 1988 were female, up from 20 percent in 1973), especially in service-sector unions. On 30 April 1988, 125 trade unionists, labor educators, and academics attended the "Women, Work, and Family Life" Conference at the headquarters of the United Auto Workers in New York City. Focusing on organizing, parenting, wage 